\title{
The reproductive response of rams to thyroidectomy: mediation by impaired inhibin feedback rather than a change in LH pulsatility
}

\author{
G. M. Anderson ${ }^{1 *}$, K. R. Lapwood ${ }^{1}$, P. G. Knight ${ }^{2}$ and T. J. Parkinson ${ }^{1}$ \\ ${ }^{1}$ Institute of Veterinary, Animal and Biomedical Sciences, Massey University, Palmerston North, \\ New Zealand; and ${ }^{2}$ School of Animal and Microbial Sciences, University of Reading, Whiteknights, \\ Reading RG6 6AJ, UK
}

\begin{abstract}
A series of experiments was conducted to examine the mechanism by which removal of the thyroid glands in seasonally suppressed rams brings about rapid testicular growth. In the first experiment, thyroidectomy at the nadir of the testicular cycle (late winter) initiated testis growth without any detectable change in the extent of spermatogenesis compared with sham-operated controls. The serum concentration of $\mathrm{FSH}$, but not $\mathrm{LH}$, was also markedly increased by thyroidectomy. In the second experiment, serum FSH concentration was again increased by thyroidectomy in late winter but there was no effect of thyroidectomy on LH concentration, LH pulses (measured in frequent blood samples) or testosterone concentration. Furthermore, there was no evidence of a change in central dopaminergic inhibition of GnRH, as measured by the pulsatile $\mathrm{LH}$ response to an i.m. injection of the dopaminergic $D_{2}$ agonist bromocriptine or antagonist sulpiride.
\end{abstract}

The rapid increase in FSH concentration occurred despite a markedly increased serum inhibin A concentration in thyroidectomized rams. Therefore, the efficacy of inhibin feedback was examined by testing the FSH-suppressive effect of an inhibin preparation $(5 \mathrm{ml}$ charcoal-stripped bovine follicular fluid i.v.) in long-term thyroidectomized and thyroid intact castrated rams. Bovine follicular fluid suppressed FSH concentrations in control rams as expected but in marked contrast, was completely without effect in thyroidectomized animals. In castrated rams, the FSH concentration was only marginally increased by thyroidectomy, indicating that there is a major component of the mediation of the effects of thyroidectomy that is testicular in origin. It was concluded that a reduction in the ability of endogenous inhibin to inhibit FSH release at the pituitary, rather than a hypothalamic mechanism, is the primary cause of the stimulation of testis growth by thyroidectomy.

\section{Introduction}

Reproduction in rams is characterized by seasonal oligospermia, and the annual cycle of testicular activity is governed by parallel changes in circulating concentrations of the gonadotrophins $\mathrm{LH}$ and FSH (Lincoln and Short, 1980; Courot and Ortavant, 1981). In the Romney breed, gonadotrophin concentrations are maximal soon after the summer solstice and testicular activity reaches a peak 2-3 months later (Barrell and Lapwood, 1979). Circulating concentrations of inhibin, a dimeric glycoprotein named for its regulatory effect on FSH synthesis and secretion, are closely correlated with the changes in testis growth and regression in rams of various breeds (Lincoln and McNeilly, 1989; Lincoln et al., 1990; McNeilly et al., 2002). Using developed isoform-specific

*Current address: Department of Anatomy and Structural Biology and Centre for Neuroendocrinology, University of Otago School of Medical Sciences, Dunedin, New Zealand.

Email: Greg.Anderson@anatomy.otago.ac.nz
ELISAs, McNeilly et al. (2002) demonstrated that the sheep is unique among all species examined to date in that the testes appear to secrete only the inhibin A isoform, whereas males of other species exclusively produce inhibin $B$.

A recently described component of the seasonal reproductive cycle in many species and in both sexes is the requirement for the presence of thyroid hormones (for example birds: Goldsmith and Nicholls, 1984; Follett and Nicholls, 1985; mammals: Jacquet et al., 1986; Nicholls et al., 1988; Shi and Barrell, 1992; Parkinson and Follett, 1994; Anderson and Barrell, 1998a). In all of these species, thyroidectomy at or just before the time of peak sexual activity prevents or delays the seasonal return to reproductive quiescence. Since the importance of the thyroid glands for seasonal reproduction in rams was first demonstrated almost a decade ago, fundamental differences have been apparent in the way thyroid gland removal affects male compared with female reproductive cycles in sheep. Principally, thyroidectomy of rams during seasonal testicular regression results in rapid, 
sustained testis growth and increased FSH secretion (for example, Parkinson and Follett, 1994), whereas in ewes the surgery has no effect if conducted during seasonal anoestrus (Thrun et al., 1997), but prevents the onset of this state if conducted during the breeding season (for example Moenter et al., 1991). The hypothalamic neuroendocrine mechanisms controlling the inhibition of rapid testicular growth and FSH secretion in ewes have received considerable attention (for example, see Webster et al., 1991; Viguié et al., 1999; Anderson et al., 2002; 2003), but mechanisms underlying rapid growth and increased FSH secretion in rams have not yet been elucidated.

In view of the sex differences in response to thyroidectomy during seasonal reproductive suppression, a set of experiments was conducted to characterize the nature of the reproductive stimulation that occurs after thyroidectomy in rams. In particular, the aim of this study was to identify whether the effect is mediated at the hypothalamus or pituitary gland. To this end, LH pulse frequency was used as a robust index of $\mathrm{GnRH}$ pulse frequency (Clarke and Cummins, 1982; Levine et al., 1982; Karsch et al., 1987), and the LH response to i.v. administration of dopaminergic agents was used to identify changes in central dopaminergic tone, as seasonal changes in dopaminergic activity modulate LH concentrations in rams (Tortonese and Lincoln, 1994a,b). The effects of thyroidectomy on the concentration of inhibin A and the feedback potency of an inhibin preparation on $\mathrm{FSH}$ release were also examined.

The seasonal pattern of gonadotrophin secretion cannot be entirely accounted for by changing steroid feedback effects in sheep and other species (Goodman and Karsch, 1981; Lincoln, 1984); however, the 'steroidindependent' component of seasonal reproduction has not been well described in rams. Therefore, an additional experiment was conducted to investigate whether the thyroid gland is required for steroid-independent seasonal changes in gonadotrophin concentrations and LH pulsatility in castrated male sheep, as they are in ovariectomized ewes (Anderson et al., 2002). The results of two individual experiments have been presented to an International Congress of Physiological Sciences satellite meeting (Actions and Interactions at the Pituitary, 2001) and the New Zealand Society of Endocrinology (published in the Proceedings of the Endocrine Society of Australia, 2002).

\section{Materials and Methods}

\section{Animals and routine procedures}

Two-year-old cross-bred (50\% South Suffolk, 25\% Finnish Landrace, 25\% Texel) (Expt 1) or New Zealand Romney (Expts 2-5) rams were used. The sheep were maintained in ambient photoperiods and temperature (lat $40^{\circ} 30^{\prime} \mathrm{S}$; mean daytime temperature annual range $22-12^{\circ} \mathrm{C}$ ) on pasture throughout the experiment and on yarding for collection of blood samples. Thyroidectomy was performed using sterile procedures as described by Moenter et al. (1991), under general anaesthesia (induction with $700 \mathrm{mg}$ ketamine and $35 \mathrm{mg}$ diazepam; maintenance with $2 \%(\mathrm{v} / \mathrm{v})$ halothane and oxygen). In cases in which animals were castrated, this operation was performed using sterile procedures at the time of thyroidectomy. For sham thyroidectomy, the operation was identical up to and including the separation of the sternohoid muscle into its two halves; the thyroid glands were located among the surrounding tissue but not removed. The effectiveness of thyroidectomy was assessed by measurement of serum total thyroxine concentration at least at 1 month intervals throughout the experiments. Blood samples (5 ml) were collected by jugular venepuncture; whole blood samples were allowed to clot at $4^{\circ} \mathrm{C}$ before harvesting the serum, which was stored at $-20^{\circ} \mathrm{C}$ until assayed. All procedures involving animals were approved by the Massey University Animal Ethics Committee.

\section{Experiment 1}

Rams were thyroidectomized (THX), sham-operated or untreated on day 0 of the experiment at the nadir of the annual reproductive cycle (August; late winter) to examine in detail the changes in testis development and FSH secretion induced by thyroidectomy. Rams were killed with an i.v. pentobarbital overdose (3000 mg) on days 0 (untreated controls), 7, 14 (THX rams) or 27 (THX rams and sham-THX controls) ( $n=5-6$ per group). Paired testes were weighed and a cross-sectional sample of testis tissue was collected and fixed in Bouin's solution before being cut into sections of $7 \mu \mathrm{m}$ and stained with haematoxylin-eosin. Microscopic analysis was conducted to ascertain when spermatogenesis was initiated relative to thyroidectomy. For 20 randomly selected seminiferous tubule cross-sections per ram, the tubule diameter was measured and a score of the extent of spermatogenic development assigned. The spermatogenesis score, described by Johnsen (1970), is based on a scale of $1-10$, where 1 represents no cells (including Sertoli cells) present in the tubule cross-section, 10 represents complete spermatogenesis with many spermatozoa present, and 5 (the lowest score assigned in this experiment) represents the presence of many spermatocytes, but the absence of spermatids or spermatozoa. Scores between 5 and 10 are based on the relative proportions of spermatozoa, spermatids and spermatocytes present. Spermatozoa were defined as having the thin, elongated head characteristic of ram spermatozoa; spermatids included early or late type and, thus, ranged from spherical to elliptical, and spermatocytes were identified by their dense heterochromatin nucleus. The presence or absence of spermatozoa in the tail of the epididymis was also determined. 
Blood serum samples were obtained twice each week throughout the experiment for measurement of FSH, $\mathrm{LH}$ and total thyroxine concentrations.

\section{Experiment 2}

Expt 1 revealed a marked difference in the effects of thyroidectomy on circulating concentrations of FSH and LH. In Expt 2 this difference was examined further by analysis of the pattern of pulsatile LH release over $4 \mathrm{~h}$ 'windows' at various times relative to thyroidectomy and the annual reproductive cycle. At the same time, pharmacological techniques were used to examine the role of the dopaminergic neural system in the response of mature rams to thyroidectomy. Rams were THX $(n=5)$ or sham-operated $(n=6)$ in late August (late winter) and received an i.m. injection of either the dopaminergic $\mathrm{D}_{2}$ receptor agonist bromocriptine methanosulphonate (0.06 $\mathrm{mg} \mathrm{kg}^{-1}, 1.5 \mathrm{mg} \mathrm{ml}^{-1}$ in $20 \%$ (v/v) ethanol) or the $\mathrm{D}_{2}$ receptor antagonist sulpiride $\left(0.6 \mathrm{mg} \mathrm{kg}^{-1}, 15 \mathrm{mg}\right.$ $\mathrm{ml}^{-1}$ in 0.1 mol tartaric acid $\mathrm{I}^{-1}$ ) at about 1 week before surgery, 1 month after surgery (early October; spring) or approaching the peak of the testicular cycle (early December; summer). The treatments and dosages were selected on the basis of their efficacy, ability to cross the blood-brain barrier and absence of side effects in similar experiments using rams (Tortonese and Lincoln, 1994). Blood samples for LH analysis were collected every $12 \mathrm{~min}$ for $4 \mathrm{~h}$ before and $4 \mathrm{~h}$ after injection to measure the response to these treatments. The vehicles used have been shown previously not to affect $\mathrm{LH}$ pulses in sheep (Meyer and Goodman, 1985); nevertheless, the appropriate vehicle was also injected i.m. immediately after the first blood sample to control for potential vehicle effects. During each of the three challenge periods either the agonist or antagonist was administered, followed 3 days later by the other treatment, so that each ram received both treatments in a randomized order. Single blood samples were also collected twice each week throughout the experiment for measurement of serum $\mathrm{FSH}$ and $\mathrm{LH}$ concentrations, as for Expt 1. In addition, testosterone, inhibin A and total thyroxine concentrations were measured in a selection of these samples. At approximately 1 month intervals, the circumference of the scrotum was measured at its fullest point as an index of testis size. At the conclusion of the experiment, in early December, testes were collected, weighed and processed for seminiferous tubule diameter and spermatogenesis score measurements as in Expt 1.

\section{Experiment 3}

Long-term (8 months) castrated and THX $(n=5)$ or castrated only (controls, $n=5$; sham thyroidectomy was not performed) rams received an inhibin preparation consisting of bovine follicular fluid (bFF), collected from a cattle abattoir facility and stripped with charcoal to remove small molecules, as described by Wallace and McNeilly (1985), to determine whether the increase in FSH concentration after thyroidectomy is mediated by reduced negative feedback of inhibin. Rams received $5 \mathrm{ml}$ of stripped bFF as an i.v. injection in November. The inhibin A concentration of this preparation was assayed to be $6.4 \mu \mathrm{g} \mathrm{m}^{-1}$. Blood samples were collected at $1 \mathrm{~h}$ intervals from -1 to $+4 \mathrm{~h}$ relative to injection and, thereafter, at $2 \mathrm{~h}$ intervals until $24 \mathrm{~h}$ after injection; sera were assayed for $\mathrm{FSH}$ and $\mathrm{LH}$ concentration.

\section{Experiment 4}

Blood samples were collected each week from April (autumn) to November (early summer) from the same long-term castrated and THX and castrated only animals used for Expt 3 and the samples assayed for FSH, LH and total thyroxine to investigate whether the thyroid glands are required for steroid- or inhibin-independent seasonal changes in gonadotrophin concentrations in rams. In addition, blood samples were collected every $12 \mathrm{~min}$ for $4 \mathrm{~h}$ during May and late November to facilitate comparison of $\mathrm{LH}$ pulses at these times.

\section{Immunoassay for $\mathrm{LH}$ and FSH}

Serum $\mathrm{LH}$ and FSH concentrations were measured in 25-150 $\mu$ l aliquots by radioimmunoassay, using methods similar to those described by Scaramuzzi et al. (1970) and Bremner et al. (1980). Values are expressed in terms of the ovine standards NIADDK-oLH-1 and NIAMDDoFSH-RP-1. lodinated ovine LH (NIADDK-oLH-1-3) and ovine FSH (NIADDK-oFSH-I-SIAFP-21) were used as tracers and primary antisera were NIADDK-rabbit-antioLH-1 (final dilution 1:500 000) and NIADDK-rabbitanti-oFSH-1 (1:100000). The mean sensitivity $(95 \%$ confidence interval at $0 \mathrm{ng} \mathrm{m}^{-1}$ ) was $0.05 \mathrm{ng}$ per tube (eight assays) and $0.03 \mathrm{ng}$ per tube (four assays) for $\mathrm{LH}$ and FSH assays, respectively. The mean intra-assay coefficients of variation were 15 and $18 \%$, for serum pools within the middle of the $\mathrm{LH}$ and $\mathrm{FSH}$ standard curves, respectively, and interassay coefficients of variation were 17 and $16 \%$ for the same serum pools.

Serum total thyroxine and testosterone concentrations were assayed in $50 \mu \mathrm{l}$ aliquots using commercially available kits (Coat-A-Count Total T4, Diagnostic Products Corp., Los Angeles, CA and Active Coated Tube Testosterone radioimmunoassay, Diagnostic Systems Laboratories, Inc, Webster, TX). The mean sensitivity was $4.0 \mathrm{nmol}$ $\mathrm{I}^{-1}$ (one assay) and $0.1 \mathrm{nmol} \mathrm{I}^{-1}$ (one assay) for the total thyroxine and testosterone assays, respectively. The mean intra-assay coefficients of variation were 10 and $2 \%$ for serum pools within the middle of the total tyroxine and testosterone standard curves, respectively.

Serum inhibin A concentration was measured using a two-site ELISA which was specifically developed for bovine and ovine samples (Knight et al., 1998). The 

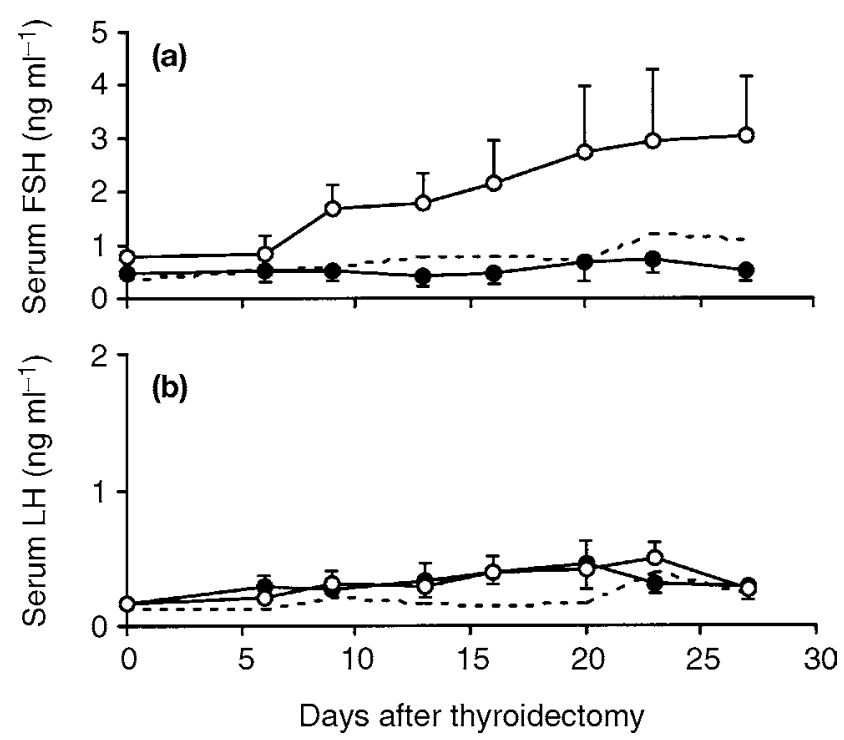

Fig. 1. Mean ( \pm SEM) serum concentrations of (a) FSH and (b) $\mathrm{LH}$ in thyroidectomized (THX, $\bigcirc)$ and sham-THX control $(\bullet ; n=6)$ rams in Expt 1. Combined data are plotted for THX rams killed on days 7, 14 and 27 of the experiment; thus $n$ for THX rams decreases from 17 to 6 . Individual data from a single ram with presumed incomplete thyroidectomy are plotted separately (dashed line).

sensitivity of the assay was improved by using a different biotinylated detection antibody (PPG 14/6), as described by Bleach et al. (2001). This antibody was raised against a synthetic peptide corresponding to amino acid sequence $1-32$ of the bovine $\alpha C$ subunit. The immobilized 'capture' antibody used (E4, raised against a synthetic peptide corresponding to the amino acid sequence 82114 of the human and ovine $\beta A$ subunit) was the same as that used in the original assay. Sensitivity of the assay was $15 \mathrm{pg} \mathrm{ml}^{-1}$ and within- and between-plate coefficients of variation were both $<12 \%$.

\section{Statistical analysis}

Data from any THX rams showing evidence of incomplete surgery (mean total thyroxine concentration of $>4 \mathrm{nmol} \mathrm{I}^{-1}$; see Anderson et al., 2002) were excluded from analysis and presented separately. Hormone concentrations below the average sensitivity were assigned a value equal to the sensitivity. For LH pulse identification in data obtained from frequent sampling periods, the method described by Goodman and Karsch (1980) was used. An LH pulse was defined as any increase in concentration in which: (i) concentrations were high relative to pre- and post-nadirs for at least two consecutive samples; (ii) the pulse reached a peak within two sampling intervals; (iii) the increment between peak and nadir concentrations exceeded the pre- and post-nadir values by at least two standard deviations of the peak value; and (iv) the amplitude exceeded the sensitivity of the assay. Pulse frequency (peaks per $4 \mathrm{~h}$ ), average pulse amplitude (peak minus preceding nadir), basal concentration (average of nadirs preceding each pulse) and mean concentration over the $4 \mathrm{~h}$ sampling period were calculated for each ram. Paired Student's $t$ tests were used to compare most $\mathrm{LH}$ pulse characteristics before and after treatment with sulpiride or bromocriptine. However, pulse frequency data were analysed using the Wilcoxon signed-rank test due to the non-parametric nature of this discrete variable. All other significant effects of treatment and time were identified using ANOVA (for repeated measures where appropriate). The Fisher least significant difference multiple comparison test was used where post hoc analysis was required to determine where significant effects occurred. Mean results \pm SEM are presented.

\section{Results}

\section{Experiments 1, 2 and 4: serum total thyroxine concentration}

One THX ram from Expt 1 and one ram from Expt 2 were deemed incompletely thyroidectomized based on mean serum total thyroxine concentrations of 18.0 and $10.1 \mathrm{nmol} \mathrm{I}^{-1}$, respectively, after surgery. In all other THX rams, serum concentrations of total thyroxine decreased from 65 to $100 \mathrm{nmol} \mathrm{I}^{-1}$ before thyroidectomy to $<4 \mathrm{nmol} \mathrm{I}^{-1}$ within 10 days after surgery; the concentration remained below or close to assay detection levels thereafter. No change in total thyroxine concentration was observed after sham thyroidectomy (data not shown).

\section{Experiment 1}

In THX rams, there was a rapid increase in FSH concentration after surgery; in contrast this did not occur in sham-operated controls $(P<0.001)$, such that significant differences were detectable from day 8 after surgery (Fig. 1a). In marked contrast, thyroidectomy did not cause a significant increase in serum LH concentration relative to sham-operated controls (Fig. 1b).

Testis mass increased progressively at each sampling date. In THX rams killed on day 27, testis mass was increased relative to sham-operated control rams killed at the same time after surgery $(P<0.05)$. The diameter of the seminiferous tubules and the spermatogenesis score were significantly increased $(P<0.05)$ in this group relative to control rams killed on day 0 . However, because these parameters tended to be increased after 27 days even in the sham THX controls, the increase could not be attributed solely to thyroidectomy (Table 1). Spermatozoa were present in the epididymal tails of all rams. 
Table 1. Effects of time after thyroidectomy on testis mass, seminiferous tubule diameter and spermatogenesis score in sheep in Expt 1

\begin{tabular}{lccc}
\hline Group & $\begin{array}{c}\text { Paired testis } \\
\text { mass }(\mathrm{g})\end{array}$ & $\begin{array}{c}\text { Seminiferous } \\
\text { tubule diameter } \\
(\mu \mathrm{m})\end{array}$ & $\begin{array}{c}\text { Spermatogenesis } \\
\text { score }\end{array}$ \\
\hline Day 0 & $436 \pm 28^{* *}$ & $232 \pm 8^{*}$ & $7.1 \pm 0.2^{* \dagger}$ \\
Day 7 & $474 \pm 27^{* *}$ & $231 \pm 7^{*}$ & $7.4 \pm 0.1$ \\
Day 14 & $485 \pm 35^{*}$ & $239 \pm 7$ & $7.2 \pm 0.2$ \\
Day 27 & $603 \pm 25^{\dagger}$ & $260 \pm 9$ & $7.6 \pm 0.1$ \\
Day 27 (sham) & $496 \pm 36^{*}$ & $248 \pm 10$ & $7.8 \pm 0.2$ \\
\hline
\end{tabular}

$* P<0.05, * * P<0.01$ versus day 27.

${ }^{\dagger} P<0.05$ versus day 27 sham-thyroidectomized controls.

Hormone profiles (Fig. 1) and testis data (not shown) from the ram with presumed incomplete thyroidectomy tended to mirror those of sham THX control rams.

\section{Experiment 2}

Before thyroidectomy in rams in the THX group, and throughout the experiment up to December in sham THX controls, serum FSH concentrations in the twiceweekly blood samples were $<1 \mathrm{ng} \mathrm{ml}^{-1}$. As in Expt 1, thyroidectomy resulted in an increase in serum $\mathrm{FSH}$ concentrations to $>2 \mathrm{ng} \mathrm{ml}^{-1}$ within 10 days; this concentration was maintained throughout the experiment $(P<0.001$ versus sham-THX controls) (Fig. 2a). FSH concentrations in sham THX rams tended to increase slightly $(P<0.01)$ throughout late November and early December. As for the previous experiment, thyroidectomy did not affect the mean LH concentration, which remained below $0.5 \mathrm{ng} \mathrm{ml}^{-1}$ in both groups throughout the experiment (Fig. 2b).

Scrotal circumference increased with time in both groups $(P<0.01)$, but was greater in THX rams than in sham THX rams at 1 month after surgery, and remained higher throughout the experiment $(P<0.05)$ (Fig. 2C). Serum testosterone concentration was not significantly affected by thyroidectomy; the concentration of this hormone generally remained low $\left(<15 \mathrm{nmol} \mathrm{I}^{-1}\right)$ throughout the experiment (Fig. 2d).

Thyroidectomy had a marked effect on the concentration of serum inhibin A. Before thyroidectomy and throughout the experiment in sham-THX controls, the mean serum inhibin A concentration was $<300 \mathrm{pg} \mathrm{ml}^{-1}$; thyroidectomy caused a twofold increase within 3 weeks of surgery; this concentration was maintained throughout the experiment $(P<0.001$ versus sham THX controls $)$ (Fig. 2e).

Thyroidectomy had no effect on LH concentration, pulse frequency or pulse amplitude during the period before agonist or antagonist injections; nor did these parameters differ significantly across the three intensive (a)
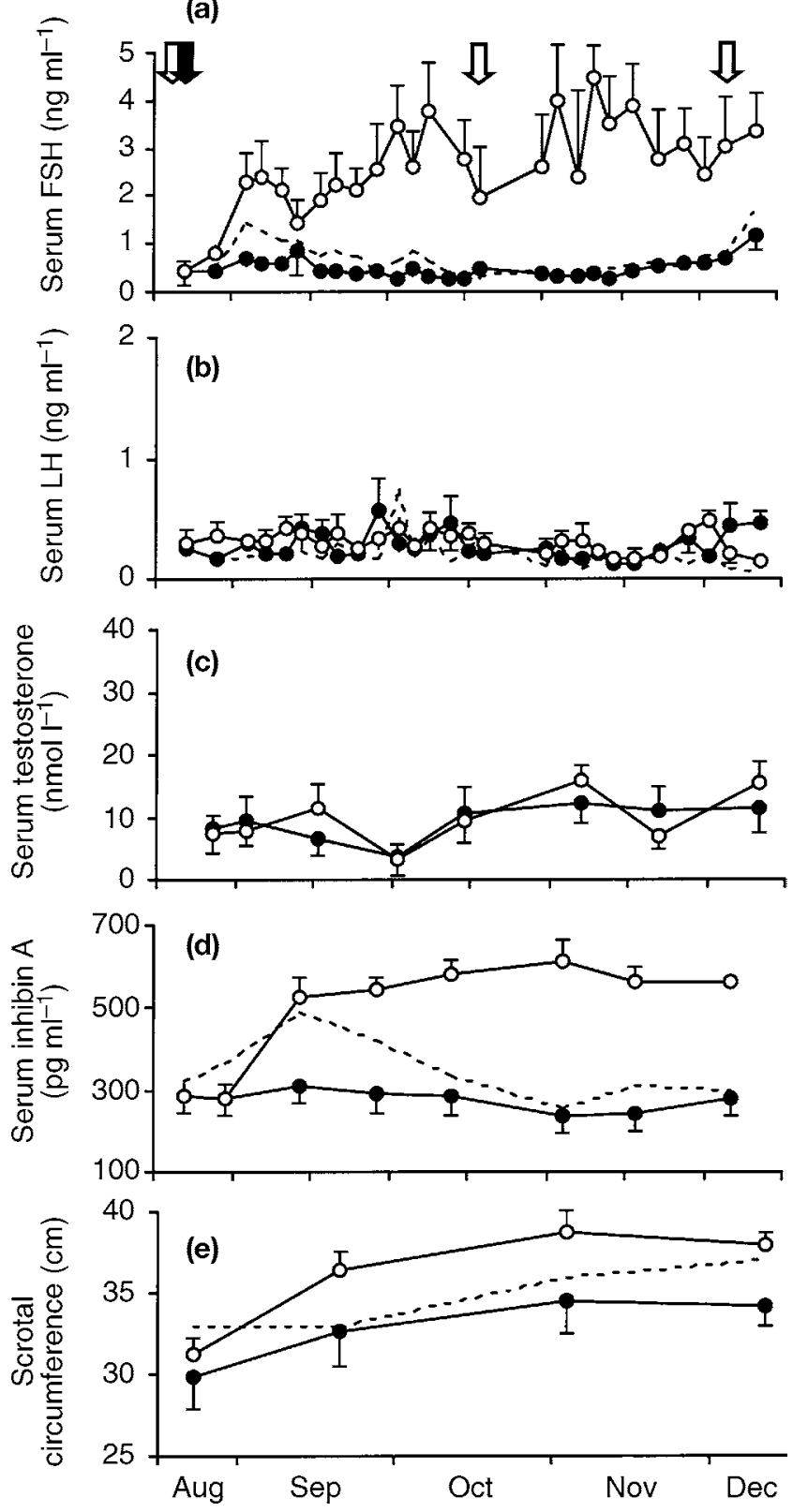

Fig. 2. Mean ( \pm SEM) serum concentrations of (a) FSH, (b) $\mathrm{LH}$, (c) testosterone and (d) inhibin $\mathrm{A}$, and (e) scrotal circumference in tyroidectomized (THX $\bigcirc ; n=5$ ) and sham-THX control $(\bullet ; n=6)$ rams in Expt 2. The filled arrow denotes the time of surgery; the open arrows show the times of frequent sampling for pulsatile $\mathrm{LH}$ secretion and dopaminergic agonist or antagonist administration. Individual data from a single ram with presumed incomplete thyroidectomy are plotted separately (dashed line; testosterone not assayed for this ram).

sampling times (Fig. 3). Overall, sulpiride caused the frequency of pulses to increase, whereas bromocriptine decreased pulse frequency. Thyroidectomy did not affect the response of any of the pulse parameters to sulpiride and bromocriptine (Fig. 4). The results from all rams were pooled to increase the sample size 


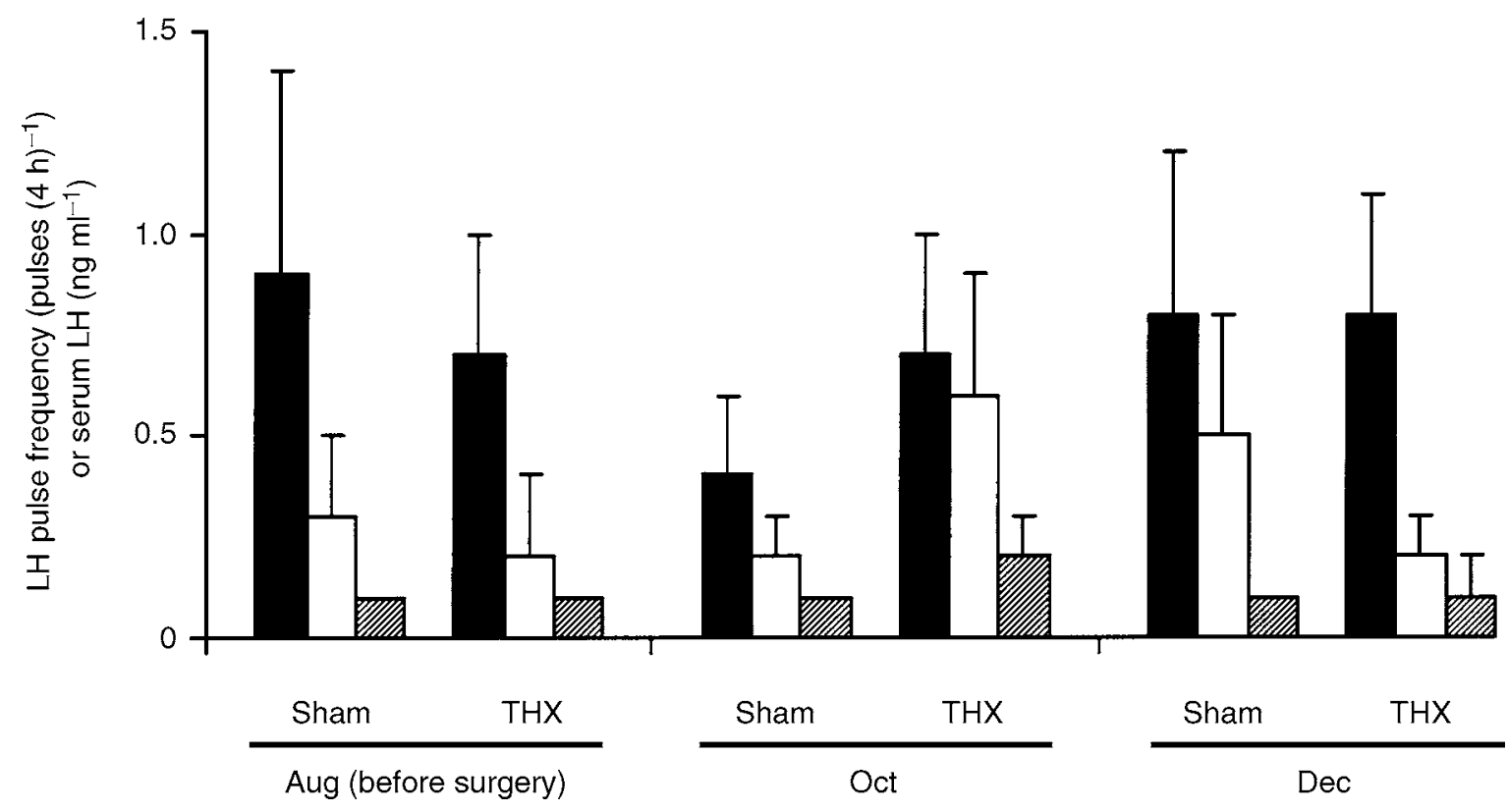

Fig. 3. Mean ( \pm SEM) LH pulse frequency $(\square)$, LH pulse amplitude ( $\square$ ) and concentration of LH (感) before treatment in thyroidectomized (THX, $n=5$ ) and sham THX (Sham, $n=6$ ) rams during three intensive sampling periods in Expt 2.

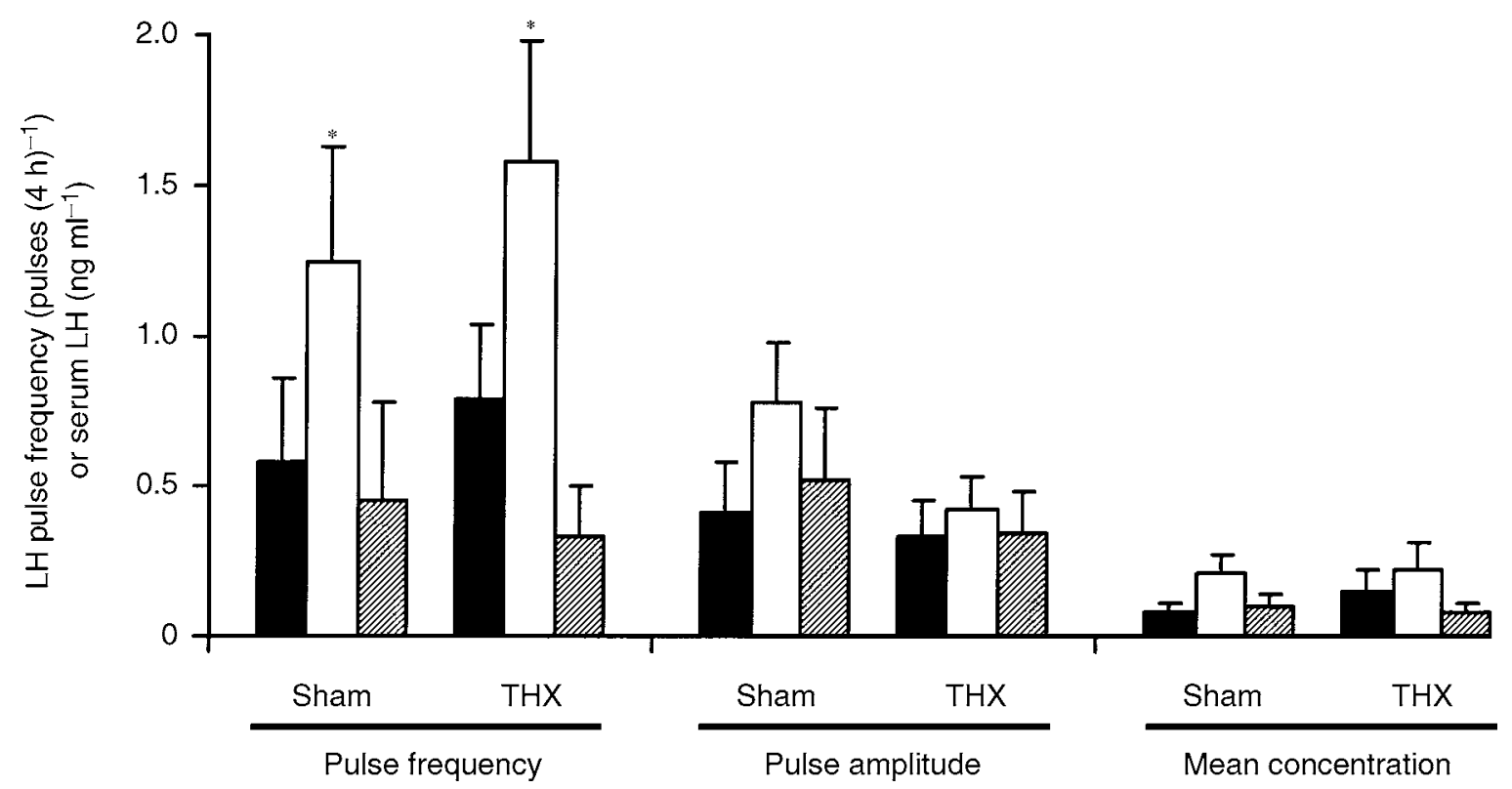

Fig. 4. Mean ( \pm SEM) LH pulse frequency, LH pulse amplitude and concentration of LH in thyroidectomized (THX) and sham THX (Sham) rams during the $4 \mathrm{~h}$ of sampling before (ם) or after the administration of dopamine $\mathrm{D}_{2}$ receptor antagonist sulpiride $(\square)$ and the $D_{2}$ receptor agonist bromocriptine (四) in Expt 2. For simplicity of presentation, data are pooled from both periods of administration after surgery (October and December). ${ }^{*} P<0.05$ versus pre-injection period.

to examine whether drug responses differed across the three intensive sampling periods. Administration of sulpiride led to an increase in LH pulse frequency of $115-198 \%$ during all three intensive sampling periods and to an increase in mean $\mathrm{LH}$ concentration of $180 \%$ during August $(P<0.05)$. When rams with no pulses during the pre-treatment injection period were removed from the analysis, treatment with bromocriptine resulted in a $36-57 \%$ decrease in pulse frequency during all three months $(P<0.05)$.

Paired testis masses at the conclusion of the experiment in early December were increased in THX rams versus controls $(631 \pm 42$ and $448 \pm 54 \mathrm{~g}$, respectively; $P<0.05)$. Similar, although not significant, trends were 

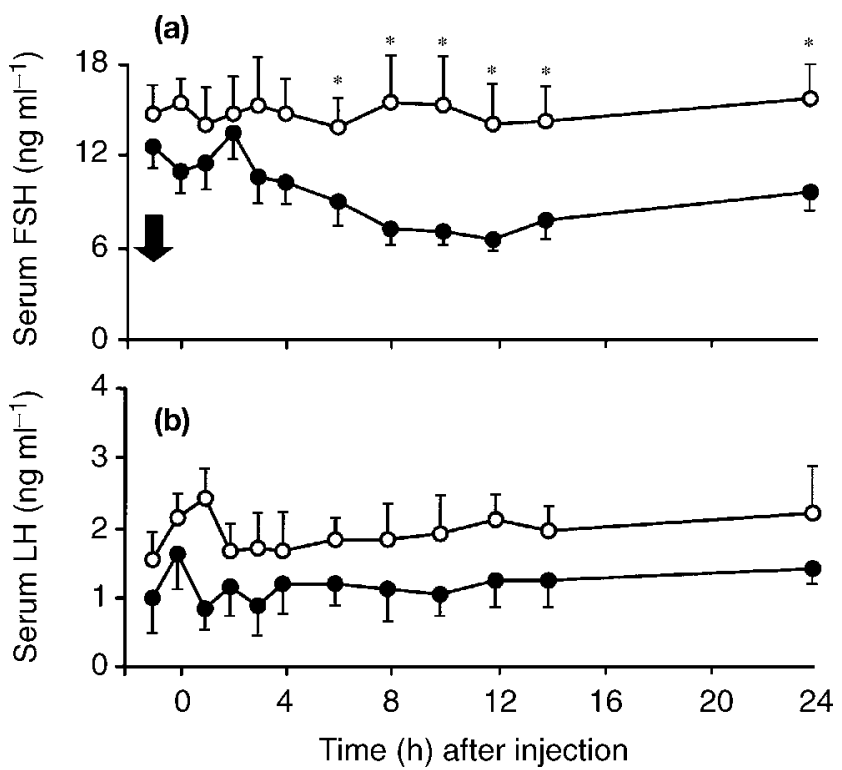

Fig. 5. Mean ( \pm SEM) serum concentrations of (a) FSH and (b) LH in thyroidectomized (THX $\bigcirc ; n=5)$ and thyroid-intact control $(\bullet$; $n=5$ ) castrate rams in Expt 3 in response to an inhibin preparation $(5 \mathrm{ml}$ charcoal-stripped bovine follicular fluid (bFF) administered i.v.). The arrow denotes the time of bFF treatment. ${ }^{*} P<0.05$ versus controls.

observed for seminiferous tubule diameter $(253 \pm 9$ and $217 \pm 15 \mu \mathrm{m} ; P=0.07)$ and spermatogenesis score $(7.6 \pm 0.4$ and $6.5 \pm 0.5 ; P=0.09)$. Spermatozoa were present in the epididymal tail of all rams. As for Expt 1, hormone profiles (Fig. 2) and testis data (not shown) from the ram with presumed incomplete thyroidectomy followed the trends of sham THX control animals, with the exception of a transient increase in serum FSH and inhibin A soon after thyroidectomy.

\section{Experiment 3}

Before bFF injections, serum FSH and LH concentrations tended to be marginally higher in THX rams than in thyroid-intact controls ( $P=0.08$ and 0.15 , respectively). As expected, treatment with bFF led to a decline in the concentration of FSH in control rams $(P<0.01)$; in marked contrast FSH concentration did not change after bFF in THX rams $(P<0.01$ versus thyroid intact controls). Nadir FSH values were reached by $12 \mathrm{~h}$ after injection; the difference between groups was significant by $4 \mathrm{~h}$ (Fig. 5a). Serum LH concentration was not affected by bFF in THX or control rams (Fig. 5b).

\section{Experiment 4}

Serum LH and FSH concentrations declined for both THX and control rams between April and November $(P<0.01)$, although the change was less marked for FSH. Thyroidectomy caused an increase in both mean FSH
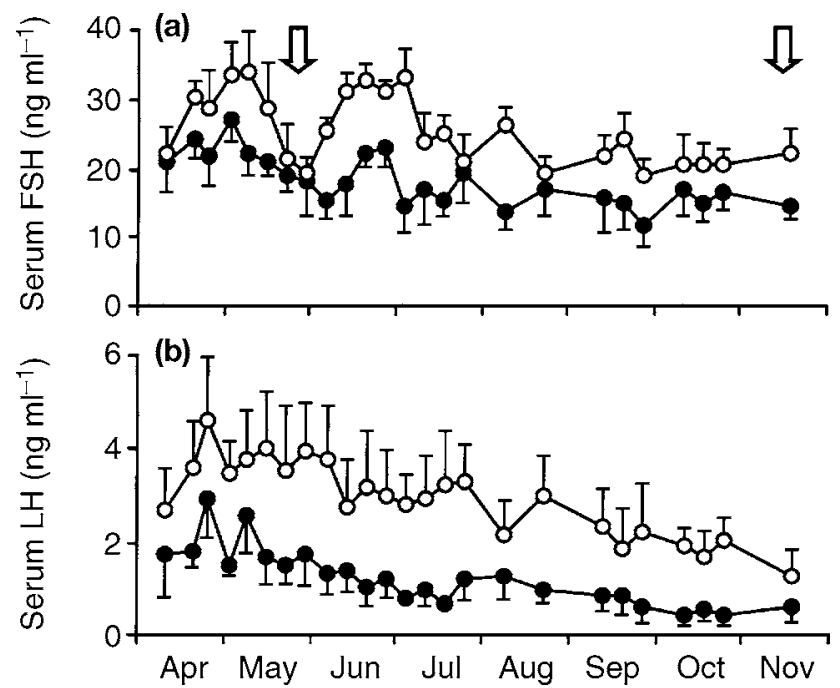

Fig. 6. Mean ( \pm SEM) serum concentrations of (a) FSH and (b) $\mathrm{LH}$ from weekly blood samples in thyroidectomized (THX $\bigcirc ; n=5$ ) and thyroid-intact control $(\bullet ; n=5)$ castrate rams in Expt 4 . Surgery was performed in late March. The open arrows show the times of frequent sampling for pulsatile $\mathrm{LH}$ secretion.

(Fig. 6a) and mean LH (Fig. 6b) concentrations throughout the experiment $(P<0.05)$. There were no effects of thyroidectomy on $\mathrm{LH}$ pulse frequency during either May or November; however, thyroidectomy tended to increase pulse amplitude at both times $(P=0.06)$ and both mean and basal LH concentration in November $(P=0.08$ and 0.10 , respectively) (Fig. 7).

\section{Discussion}

The results of the present study are the first to describe the mechanism by which thyroidectomy at the nadir of the testicular cycle induces rapid and sustained testis growth, although the neuroendocrine mechanisms by which thyroidectomy prevents the onset of seasonal anoestrus in female sheep have been well-studied (for example, see Webster et al., 1991; Viguié et al., 1999; Anderson et al., 2002, 2003). In particular, the results of the present study demonstrate an important role of the thyroid glands in facilitating normal inhibin feedback to the FSH-secreting gonadotrophs, indicating that the effects of thyroidectomy occur primarily at the anterior pituitary rather than at that of the hypothalamic $\mathrm{GnRH}$ pulse generator.

An important finding in the present study is that the effect of thyroidectomy at the nadir of the testicular cycle on gonadotrophin secretion was confined to FSH. Analysis of LH pulse frequency, which provides a robust indicator of the frequency of hypothalamic GnRH (Clarke and Cummins, 1982; Levine et al., 1982; Karsch et al., 1987), did not show an effect of thyroidectomy. Even in the absence of testicular steroids (Expt 4) there was no effect on pulse frequency; the increased mean $\mathrm{LH}$ 

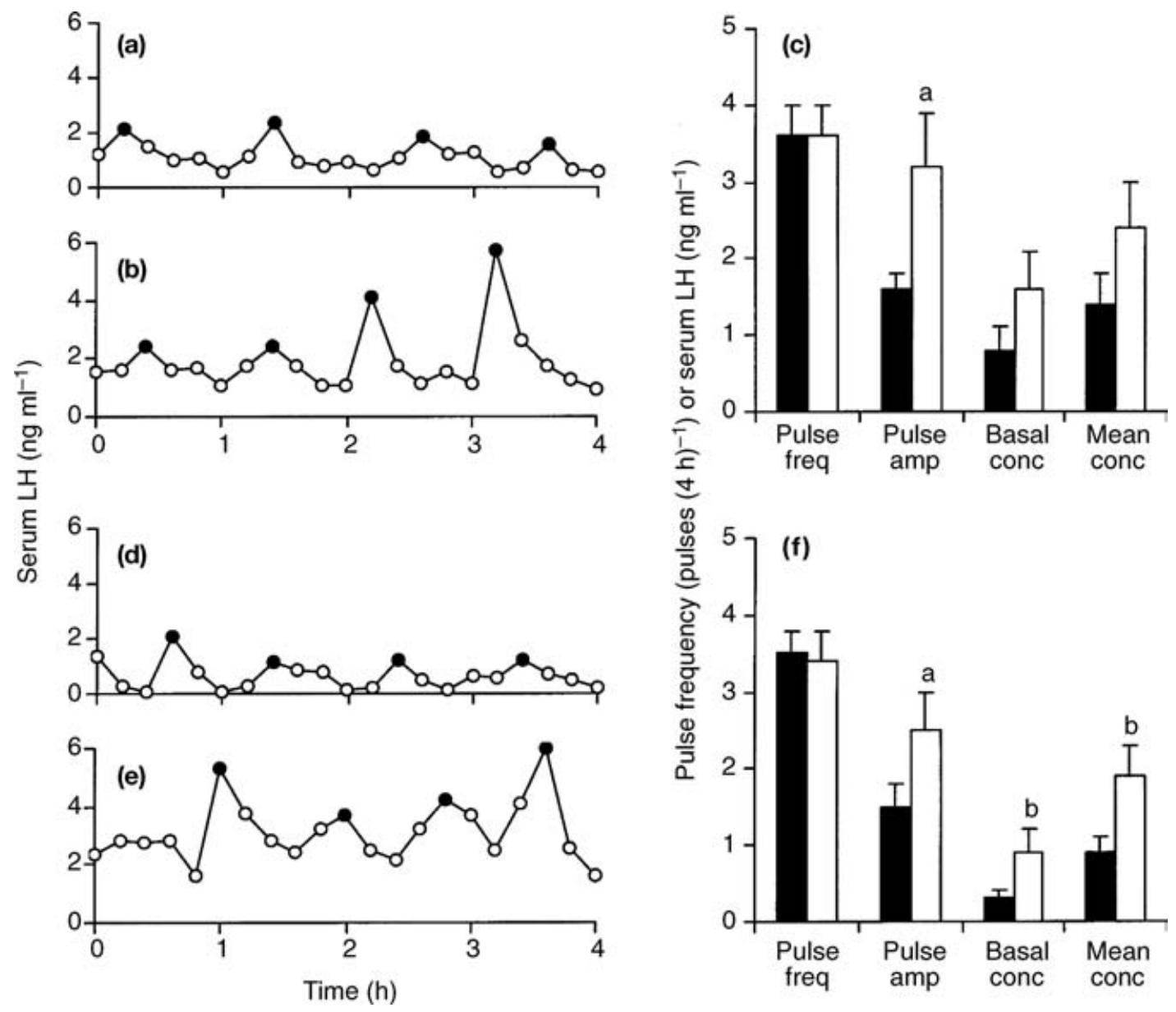

Fig. 7. (a,b,d,e) Individual serum LH pulse profiles and (c,f) characteristics of pulsatile LH secretion (pulse frequency (Pulse freq), pulse amplitude (Pulse amp), basal concentration (Basal conc) and mean concentration (Mean conc)) during $(\mathrm{a}-\mathrm{c})$ May and $(\mathrm{d}-\mathrm{f})$ November in Expt 4. Data are representative of $(\mathrm{a}, \mathrm{d})$ sham-operated control rams $(n=5 ; \mathbf{\square})$ and (b,e) thyroidectomized (THX) rams $(n=5 ; \square)$. Peaks of LH pulses are denoted by filled circles. $a, P=0.06$ versus controls and $b, 0.08<P>0.10$ versus controls.

concentration in THX castrate rams appeared to be due to increased pulse amplitude. Although this could have been due to an increase in GnRH pulse size, it has also been reported that the pituitary responsiveness to $\mathrm{GnRH}$ can be increased by thyroidectomy (Anderson and Barrell, 1998a). These results strongly indicate that the effects of thyroidectomy at this time of year occur below the level of $\mathrm{GnRH}$ release (that is, outside the hypothalamus). The lack of an effect on the LH response to administration of dopaminergic agents, a technique which has been used to identify changes in the central dopaminergic tone modulating $\mathrm{GnRH}-\mathrm{LH}$ release in rams (Tortonese and Lincoln, 1994a,b), provides further evidence that the brain mechanisms controlling $\mathrm{GnRH}$ release were not altered by thyroidectomy in the experiments. Specifically, if thyroidectomy had induced reproductive activity via a reduction in dopaminergic inhibition of GnRH secretion, greater bromocriptineinduced LH suppression and less sulpiride-induced LH stimulation in THX rams would have been expected, in a similar manner to the situation that occurs in short day photostimulated rams (Tortonese and Lincoln, 1994a). This was clearly not the case; instead the equally strong stimulation of pulse frequency by sulpiride and the comparatively weak responses to bromocriptine for both groups implies that GnRH pulses were equally suppressed by endogenous dopamine in all rams at the times of treatments.

The concept of thyroid hormones acting outside of the central $\mathrm{GnRH}-\mathrm{LH}$ system to modulate seasonal reproduction is in contrast to results from similar studies in ewes, in which the seasonal decline in $\mathrm{GnRH}$ and LH pulse frequency was prevented by thyroidectomy (for example, see Webster et al., 1991) and thyroid hormones were shown to act within the brain (Viguié et al., 1999; Anderson et al., 2003). However, a fundamental difference is that the present study examined the rapid increase in reproductive activity after thyroidectomy 
during the seasonal nadir of sexual activity, whereas the other studies examined failure of the onset of seasonal anoestrus after thyroidectomy during the breeding season in ewes. The latter process presumably requires establishment of inhibitory neural pathways afferent to GnRH neurones (Meyer and Goodman, 1985; Thiéry et al., 1989; Lehman et al., 1996), a process that would probably require thyroid hormones, given that there is a similar requirement during neonatal development (Koibuchi and Chin, 2000). The present findings do not preclude a similar central effect of thyroidectomy in males in maintaining the active reproductive state after the normal peak of sexual activity. Indeed, there is evidence that this effect does involve $\mathrm{LH}$ in male sheep (Parkinson and Follett, 1995) and red deer (Shi and Barrell, 1992). In the present study the effects of thyroidectomy after the peak of sexual activity in gonad intact rams was not examined, but in Expt $4 \mathrm{LH}$ was measured throughout this period in castrates. As with the aforementioned studies, in the present study $\mathrm{LH}$ concentration was increased in THX rams relative to controls, although a residual extent of seasonality was still apparent. Such low-amplitude seasonal fluctuations which persist after thyroidectomy have been reported in long-term studies of gonad-intact rams (Parkinson and Follett, 1995), red deer stags (Shi and Barrell, 1992) and ovariectomized ewes (Anderson et al., 2002).

The divergent effects on $\mathrm{LH}$ and FSH led to speculation that changes in the function of inhibin may be responsible for the induction of reproductive activity in THX rams, as this hormone specifically regulates $\mathrm{FSH}$ secretion. The fact that in the present study $\mathrm{FSH}$ was markedly increased by thyroidectomy in gonad-intact rams but only marginally increased in castrated rams (Expt 4) supports the concept that the mediator of the effects of thyroidectomy is mostly testicular in origin. Conceptually, the effect could be caused either by a decrease in the concentration of inhibin or by impaired inhibin feedback potency in THX rams. Measurement of inhibin A the form produced by the Sertoli cells of adult rams; McNeilly et al., 2002) concentration in THX and control rams (Expt 2) did not support the former hypothesis. Instead, inhibin A was markedly increased after thyroidectomy, probably as a result of increased secretion in response to increased FSH concentrations (Voglmayr et al., 1992; Sanford et al., 2002) or decreased inhibin clearance (Tilbrook et al., 1999a). Consequently, the question of whether THX rams exhibited a normal response to injection of inhibin (Expt 3) was of some importance. bFF suppressed $\mathrm{FSH}$ secretion in control rams as expected (Tilbrook et al., 1992) but, in marked contrast, was completely without effect in THX animals. These results support the hypothesis that the increase in circulating FSH (and hence testis size) induced by thyroidectomy is mediated by a reduction in the ability of endogenous inhibin to inhibit FSH release. It could be argued that the effect of thyroidectomy on inhibin feedback potency was only demonstrated in castrates, which lack the synergistic feedback effects of testosterone (Tilbrook et al., 1999b; Tillbrook and Clarke, 2001). However, the concentration of $\mathrm{FSH}$ remained increased in THX rams in Expt 2 of the present study despite a twofold increase in the concentration of inhibin A, supporting the concept that endogenous inhibin is rendered ineffective in the absence of thyroid hormones even in gonad intact rams. Furthermore, this effect occurred when the concentration of testosterone was at its seasonal minimum, indicating that interactions with this steroid are not a major factor in the response to thyroidectomy. A remarkably similar lack of inhibin feedback and hypersecretion of FSH has been demonstrated in ovine freemartinism (Parkinson et al., 2001).

In Expt 3, charcoal-stripped bFF was used as a source of exogenous inhibin, rather than recombinant inhibin $\mathrm{A}$. Although bFF contains several non-steroidal components other than inhibin that might influence gonadotrophin secretion, such as activins and follistatins, there is good evidence to support the notion that the effects of this preparation on FSH secretion are due entirely to its inhibin content. Knight et al. (1991) showed that ewes that had been immunized against the $\alpha$ subunit of bovine inhibin were unable to respond to bFF injections with a reduction in FSH concentration. This finding, together with the close similarity between the results of the present study (in control rams) and those from studies using recombinant inhibin $\mathrm{A}$ (for example, see Tilbrook et al., 1999a), provides justification for the use of charcoalstripped bFF as a convenient source of inhibin in this type of experiment.

The reduction in inhibin efficacy after thyroidectomy may be mediated by changes in the expression of inhibin receptors within the anterior pituitary gland or in their signal transduction pathway. The mechanism of inhibin signalling is not well elucidated, although two putative inhibin receptors, p120 (Chong et al., 2000) and $\beta$-glycan (Lewis et al., 2000), have been characterized, which may mediate specific signalling pathways or act by blocking activin signalling (Matzuk, 2000; Robertson et al., 2000). Interestingly, given that the sheep appears to be unique among species in its production of inhibin $A$ rather than $B$, a specific inhibin binding site has been reported in sheep pituitary tissue that has a much higher affinity for inhibin A than for inhibin B (Hertan et al., 1999). If the ability of this site to bind inhibin and regulate $\mathrm{FSH}$ secretion were dependent on thyroid hormones, thyroidectomy might be expected to impair inhibin feedback in rams, but not males of the other species that have been examined to date, which produce exclusively inhibin B (for example, humans: Illingworth et al., 1996; chimpanzees: Kondo et al., 2000; rats: Woodruff et al., 1996; hamsters: Jin et al., 2001). In this regard, thyroidectomy (G. M. Anderson, unpublished) or suppression of thyroid hormone with propylthyiuracil (Maia et al., 1995) does not increase testis growth rate 
in peripubertal male rats, although transient neonatal hypothyroidism does result in a similar phenomenon at the time of puberty (Cooke and Meisami, 1991; Kirby et al., 1992; Van Haaster et al., 1992).

The rapid increase observed in testis size and $\mathrm{FSH}$ concentration after thyroidectomy in spring is in line with data from Welsh Mountain rams (Parkinson and Follett, 1994; Parkinson et al., 1995), but the effects of thyroidectomy at this time of year on spermatogenesis and testosterone production have not been reported. Neither spermatogenesis nor testosterone production was significantly affected relative to sham-operated controls in the present study. The previously discussed lack of effect on LH secretion would indeed predict a normal concentration of testosterone production in THX rams, but the markedly increased concentration of FSH in these animals might equally be expected to lead to an enhancement of sperm production (Kilgour et al., 1994). It may be that 27 days, the longest treatment period used in Expt 1, was insufficient for such an effect to be manifested. In adult rats, suppression of thyroid hormone secretion causes maturation arrest of spermatogenesis and reduces the numbers of Sertoli and Leydig cells (Tahmaz et al., 2000), but fertility is maintained in longterm THX rams (Parkinson and Follett, 1994) and red deer stags (Anderson and Barrell, 1998b).

In addition to possibly being a species-specific phenomenon, the effect of thyroidectomy at the time of sexual quiescence is also restricted to males. In female sheep, thyroidectomy early in the anoestrous season does not appear to result in markedly earlier resumption of gonadal (Parkinson, 1994) or reproductive neuroendocrine (Thrun et al., 1997) activity; nor is the concentration of inhibin $A$ increased by thyroidectomy in these animals (G. M. Anderson and P. G. Knight, unpublished). On account of the fact that the seasonal onset of ovarian cyclicity requires increased LH secretion (Goodman, 1994), whereas testicular growth and spermatogenesis are responsive to fluctuations in $\mathrm{FSH}$ alone (Kilgour et al., 1994; Allan et al., 2001), an effect of thyroidectomy on $\mathrm{FSH}$ regulation during anoestrus may not have been noticed in females. Until inhibin-FSH feedback is evaluated in thyroidectomized female sheep; the sex difference will not be conclusively resolved.

In conclusion, the results of the present experiments provide little support for a central mechanism involving increased $\mathrm{GnRH}-\mathrm{LH}$ release as the cause of the stimulation of testicular growth by thyroidectomy in spring. Instead, the concept that in THX rams a reduction in the negative feedback efficacy of endogenous inhibin at the anterior pituitary increases FSH secretion, which in turn stimulates testicular activity is favoured. The inability of inhibin to regulate FSH secretion in the absence of thyroid hormones occurs despite greatly increased serum inhibin A concentrations, presumably a result of high concentrations of FSH maximally stimulating Sertoli cell secretion.
The authors extend grateful thanks to the Foundation for Research, Science and Technology for funding in the form of a New Zealand Science and Technology postdoctoral fellowship, and to the National Pituitary Agency for LH and FSH radioimmunoassay reagents.

\section{References}

Allan CM, Haywood M, Swaraj S et al. (2001) A novel transgenic model to characterize the specific effects of follicle-stimulating hormone on gonadal physiology in the absence of luteinizing hormone actions Endocrinology 142 2213-2220

Anderson GM and Barrell GK (1998a) Effects of thyroidectomy and thyroxine replacement on seasonal reproduction in the red deer hind Journal of Reproduction and Fertility $113239-250$

Anderson GM and Barrell GK (1998b) Out-of-season breeding in thyroidectomized red deer hinds Proceedings of the New Zealand Society of Animal Production 58 20-24

Anderson GM, Connors JM, Hardy SL, Valent M and Goodman RL (2002) Thyroid hormones mediate steroid-independent seasonal changes in luteinizing hormone pulsatility in the ewe Biology of Reproduction $\mathbf{6 6}$ 701-706

Anderson GM, Hardy SL, Valent M, Billings HJ, Connors JM and Goodman RL (2003) Evidence that thyroid hormones are required within the premammilary region of the brain for the termination of the breeding season in the ewe Endocrinology 144 2892-2901

Barrell GK and Lapwood KR (1979) Seasonality of semen production and plasma luteinizing hormone, testosterone and prolactin levels in Romney, Merino and Polled Dorset rams Animal Reproduction Science $1213-228$

Bleach ECL, Glencross RG, Feist SA, Groome NP and Knight PG (2001) Plasma inhibin A in heifers: relationship with gonadotropins, steroids and follicle dynamics during the estrous cycle and after treatment with bovine follicular fluid Biology of Reproduction 64 743-752

Bremner WJ, Findlay JK, Lee VW, de Kretser DM and Cumming IA (1980) Feedback effects of the testis on pituitary responsiveness to luteinizing hormone-releasing hormone infusions in the ram Endocrinology $\mathbf{1 0 6}$ 329-336

Chong H, Pangas SA, Bernard DJ, Wang E, Gitch J, Chen W, Draper LB, Cox ET and Woodruff TK (2000) Structure and expression of a membrane component of the inhibin receptor system Endocrinology 1412600 2607

Clarke IJ and Cummins JT (1982) The temporal relationship between gonadotrophin releasing hormone $(\mathrm{GnRH})$ and luteinizing hormone $(\mathrm{LH})$ secretion in ovariectomized ewes Endocrinology 111 1737-1739

Cooke PS and Meisami E (1991) Early hypothyroidism in rats causes increased adult testis and reproductive organ size but does not change testosterone levels Endocrinology 129 237-243

Courot M and Ortavant R (1981) Endocrine control of spermatogenesis in the ram Journal of Reproduction and Fertility Supplement 30 47-60

Follett BK and Nicholls TJ (1985) Influences of thyroidectomy and thyroxine replacement on photoperiodically controlled reproduction in quail Journal of Endocrinology 107 211-221

Goldsmith AR and Nicholls TJ (1984) Thyroidectomy prevents the development of photorefractoriness and the associated rise in plasma prolactin in starlings General and Comparative Endocrinology 54256 263

Goodman RL (1994) Neuroendocrine control of the ovine estrous cycle. In The Physiology of Reproduction 2nd Edn. Vol. 2 pp 659-709 Eds E Knobil and JD Neill. Raven Press, New York

Goodman RL and Karsch FJ (1980) Pulsatile secretion of luteinizing hormone: differential suppression by ovarian steroids Endocrinology $\mathbf{1 0 7}$ 1286-1289

Goodman RL and Karsch FJ (1981) A critique of the evidence on the importance of steroid feedback to seasonal changes in gonadotrophin secretion Journal of Reproduction and Fertility Supplement 30 1-13 
Hertan R, Farnworth PG, Fitzsimmons KL and Robertson DM (1999) Identification of high affinity binding sites for inhibin on ovine pituitary cells in culture Endocrinology 140 6-12

Illingworth PJ, Groome NP, Byrd W, Rainey WE, McNeilly AS, Mather JP and Bremner WJ (1996) Inhibin-B: a likely candidate for the physiologically important form of inhibin in men Journal of Clinical Endocrinology and Metabolism 81 1321-1325

Jacquet J-M, Coutant C, Maurel D, Boissin-Agasse L and Boissin J (1986) Influence de la thyroïdectomie sur les variations, au cours du printemps et de l'été de l'activité testiculaire et de la prolactinémie chez le vison Comptes Rendus des Seances de L'Academie des Sciences, Paris [III] 303 367-370

Jin W, Wada S, Arai KI, Kishi H, Herath CB, Watanabe G, Suzuki AK, Groome NP and Taya K (2001) Testicular secretion of inhibin in the male golden hamster (Mesocricetus auratus) Journal of Andrology 22 207-211

Johnsen SG (1970) Testicular biopsy score count - a method for registration of spermatogenesis in human testis: normal values and results in 335 hypogonadal males Hormones $12-25$

Karsch FJ, Cummins JT, Thomas GB and Clarke IJ (1987) Steroid feedback inhibition of pulsatile secretion of gonadotropin-releasing hormone in the ewe Biology of Reproduction 36 1207-1218

Kilgour RJ, Courot M, Pisselet C, Dubois MP and Sairam MR (1994) Inhibition of FSH but not $\mathrm{LH}$ affects spermatogenesis in the mature ram Animal Reproduction Science 34 253-264

Kirby JD, Jetton AE, Cooke PS, Hess RA, Bunick D, Ackland JF, Turek FW and Schwartz NB (1992) Developmental hormonal profiles accompanying the neonatal hypothyroidism-induced increase in adult testicular size and sperm production in the rat Endocrinology 131 559565

Knight PG, Wrathall JHM, Glencross RG and McLeod BJ (1991) Effects of bovine follicular fluid on the secretion of LH and FSH in inhibinimmunized seasonally anoestrous ewes Journal of Endocrinology 128 403-410

Knight PG, Feist SA, Tannetta DS, Bleach ECL, Fowler PA, $\mathrm{O}^{\prime}$ Brien $\mathrm{M}$ and Groome NP (1998) Measurement of inhibin-A ( $\alpha \beta A$ dimer) during the oestrous cycle, after manipulation of ovarian activity and during pregnancy in ewes Journal of Reproduction and Fertility 113 159-166

Koibuchi N and Chin WW (2000) Thyroid hormone action and brain development Trends in Endocrinology and Metabolism 11 123-128

Kondo M, Udono T, Jin W, Shimizu K, Funakoshi M, Itoh M, Watanabe G, Groome NP and Taya K (2000) Changes in plasma concentrations of inhibin $\mathrm{A}$ and inhibin $\mathrm{B}$ throughout sexual maturation in the male chimpanzee Endocrine Journal 47 707-714

Lehman MN, Durham DM, Jansen HT, Adrian B and Goodman RL (1996) Dopaminergic A14/A15 neurons are activated during estradiol negative feedback in anestrous, but not breeding season, ewes Endocrinology 137 4443-4450

Levine JE, Pau K-YF, Ramirez VD and Jackson GL (1982) Simultaneous measurement of luteinizing hormone releasing hormone and luteinizing hormone release in unanesthetized sheep Endocrinology 111 14491455

Lewis KA, Gray PC, Blount AL, MacConell LA, Wiater E, Bilezikjian LM and Vale W (2000) Betaglycan binds inhibin and can mediate functional antagonism of activin signalling Nature 404 411-414

Lincoln GA (1984) Central effects of photoperiod on reproduction in the ram revealed by use of the testosterone clamp Journal of Endocrinology 103 233-241

Lincoln GA and McNeilly AS (1989) Inhibin concentrations in the peripheral blood of rams during a cycle in testicular activity induced by changes in photoperiod or treatment with melatonin Journal of Endocrinology 120 R9-R13

Lincoln GA and Short RV (1980) Seasonal breeding: nature's contraceptive Recent Progress in Hormone Research 36 1-52

Lincoln GA, Lincoln CE and McNeilly AS (1990) Seasonal cycles in the blood plasma concentration of follicle stimulating hormone, inhibin and testosterone, and testicular size in rams of wild, feral and domesticated breeds of sheep Journal of Reproduction and Fertility $\mathbf{8 8}$ 623-633
McNeilly AS, Souza CJH, Baird DT, Swanston IA, McVerry J, Crawford J, Cranfield M and Lincoln GA (2002) Production of inhibin A not B in rams: changes in plasma inhibin $A$ during testis growth, and expression of inhibin/activin subunit mRNA and protein in adult testis Reproduction 123 827-835

Maia AL, Favaretto AL, Carvaho TL, Rodrigues JA and lazigi N (1995) Hypothyroidism affects pulsatile LH secretion in pubertal orchiectomized rats Archives of Physiology and Biochemistry 103 516-520

Matzuk MM (2000) In search of binding-identification of inhibin receptors Endocrinology 141 2281-2284

Meyer SL and Goodman RL (1985) Neurotransmitters involved in mediating the steroid-dependent suppression of pulsatile luteinizing hormone secretion in anestrous ewes: effects of receptor antagonists Endocrinology 116 2054-2061

Moenter SM, Woodfill CJI and Karsch FJ (1991) Role of the thyroid gland in seasonal reproduction: thyroidectomy blocks seasonal suppression of reproductive neuroendocrine activity in ewes Endocrinology 1281337 1344

Nicholls TJ, Follett BK, Goldsmith AR and Pearson H (1988) Possible homologies between photorefractoriness in sheep and birds: the effect of thyroidectomy on the length of the ewe's breeding season Reproduction, Nutrition, Development 28 375-385

Parkinson TJ (1994) The role of thyroid hormones in reproductive seasonality The Endocrine Society of Australia Proceedings 42 209-210

Parkinson TJ and Follett BK (1994) Effect of thyroidectomy on seasonality in rams Journal of Reproduction and Fertility 101 51-58

Parkinson TJ and Follett BK (1995) Thyroidectomy abolishes seasonal testicular cycles in Soay rams Proceedings of the Royal Society of London Series B 259 1-6

Parkinson TJ, Douthwaite JA and Follett BK (1995) Responses of prepubertal and mature rams to thyroidectomy Journal of Reproduction and Fertility 104 51-56

Parkinson TJ, Smith KC, Long SE, Douthwaite JA, Mann GE and Knight PG (2001) Inter-relationships between gonadotrophins, reproductive steroids and inhibin in freemartin ewes Reproduction 122 397-409

Robertson DM, Hertan R and Farnworth PG (2000) Is the action of inhibin mediated via a unique receptor? Reviews of Reproduction 5 131-135

Sanford LM, Price CA, Leggee DG, Baker SJ and Yarney TA (2002) Role of $\mathrm{FSH}$, numbers of FSH receptors and testosterone in the regulation of inhibin secretion during the seasonal testicular cycle of adult rams Reproduction 123 269-280

Scaramuzzi RJ, Caldwell BV and Moor RM (1970) Radioimmunoassay of LH and estrogen during the estrous cycle of the ewe Biology of Reproduction 3 110-119

Shi ZD and Barrell GK (1992) Requirement of thyroid function for the expression of seasonal reproductive and related changes in red deer (Cervus elaphus) stags Journal of Reproduction and Fertility 94251 259

Tahmaz L, Gokalp A, Kibar Y, Kocak I, Yalcin O and Ozercan Y (2000) Effect of hypothyroidism on the testes in mature rats and treatment with levothyroxine and zinc Andrologia 32 85-89

Thiéry J-C, Martin GB, Tillet Y, Caldani M, Quentin M, Jamain C and Ravault JP (1989) Role of hypothalamic catecholamines in the regulation of luteinizing hormone and prolactin secretion in the ewe during seasonal anestrus Neuroendocrinology 49 80-87

Thrun LA, Dahl GE, Evans NP and Karsch FJ (1997) Effect of thyroidectomy on maintenance of seasonal reproductive suppression in the ewe Biology of Reproduction $\mathbf{5 6}$ 1035-1040

Tilbrook AJ and Clarke IJ (2001) Negative feedback regulation in the secretion and actions of gonadotropin-releasing hormone in males Biology of Reproduction 64 735-742

Tilbrook AJ, de Krester DM and Clarke IJ (1992) A role for inhibin in the regulation of follicle stimulating hormone in male domestic animals Domestic Animal Endocrinology 9 243-260

Tilbrook AJ, de Krester DM and Clarke IJ (1999a) Changes in the suppressive effects of recombinant inhibin A on FSH secretion in ram lambs during sexual maturation: evidence for alterations in the clearance rate of inhibin Journal of Endocrinology 161 219-229 
Tilbrook AJ, de Krester DM and Clarke IJ (1999b) Seasonal changes in the negative feedback regulation of the secretion of the gonaotrophins by testosterone and inhibin in rams Journal of Endocrinology 160155 167

Tortonese DJ and Lincoln GA (1994a) Photoperiodic modulation of the dopaminergic control of pulsatile $\mathrm{LH}$ secretion in sheep Journal of Endocrinology 143 25-32

Tortonese DJ and Lincoln GA (1994b) Effects of melatonin in the medial basal hypothalamus $(\mathrm{MBH})$ on the secretion of gonadotrophins in the sheep: role of dopaminergic pathways Journal of Endocrinology 146 543-552

Van Haaster LH, De Jong FH, Docter R and De Rooij DG (1992) The effect of hypothyroidism on Sertoli cell proliferation and differentiation and hormone levels during testicular development in the rat Endocrinology 131 1574-1576

Viguié C, Battaglia DF, Krasa HB, Thrun LA and Karsch FJ (1999) Thyroid hormones act primarily within the brain to promote the seasonal inhibition of luteinizing hormone secretion in the ewe Endocrinology 140 1111-1117

Voglmayr JK, Jolley D, Vale W, Willoughby D, Moser A, So C-K, Chen C-L and Bardin CW (1992) Effects of follicle-stimulating hormone on inhibin release by different testicular compartments in the adult ram Biology of Reproduction 47 573-581

Wallace JM and McNeilly AS (1985) Increase in ovulation rate after treatment of ewes with bovine follicular fluid in the luteal phase of the oestrous cycle Journal of Reproduction and Fertility 73 505-515

Webster JR, Moenter SM, Barrell GK, Lehman MN and Karsch FJ (1991) Role of the thyroid gland in seasonal reproduction III. Thyroidectomy blocks seasonal suppression of gonadotropin-releasing hormone secretion in sheep Endocrinology 129 1635-1643

Woodruff TK, Besecke LM, Groome N, Draper LB, Schwartz NB and Weiss J (1996) Inhibin A and inhibin B are inversely correlated to folliclestimulating hormone, yet are discordant during the follicular phase of the rat estrous cycle, and inhibin A is expressed in a sexually dimorphic manner Endocrinology 137 5463-5467

Received 20 March 2003.

First decision 15 April 2003.

Revised manuscript received 5 May 2003.

Accepted 20 May 2003. 